\title{
ANALISIS INDEKS PEMBANGUNAN BERWAWASAN KEPENDUDUKAN \\ (IPBK) \& INDEKS PEMBANGUNAN MANUSIA (IPM) \\ DI PROVINSI BENGKULU
}

\author{
Afid Nurkholis \\ Email: afidnurkholis@gmail.com
}

\begin{abstract}
ABSTRAK
Kesejahteraan manusia yang dalam teori pembangunan manusia diukur melalui tiga aspek (kesehatan, pendidikan, dan ekonomi). Penilaian terhadap sumberdaya manusia merupakan salah satu konsep yang mulai dilakukan oleh para ahli dunia. Penilaian ini bertujuan untuk melakukan analisis terhadap kondisi sumberdaya manusia di Provinsi Bengkulu. Indeks Pembangunan Berwawasan Kependudukan (IPBK) \& Indeks Pembangunan Manusia digunakan untuk mengukur SDM. SDM yang bernilai baik tentunya akan menjadikan kehidupan di Provinsi Bengkulu lebih baik. IPBK Provinsi Bengkulu di tahun 2014 tergolong kelas sedang di tingkat Indonesia, sedangkan kabupaten/kota tergolong tinggi higga sangat tinggi kecuali Kabupaten Seluma, Lebong, dan Bengkulu Tengah yang tergolong sedang. IPBK dan IPM Provinsi Bengkulu menunjukkan korelasi yang positif. Hal ini dikarenakan dimensi pengukuran kedua metode saling berkorelasi. IPBK dan IPM Provinsi Bengkulu tergolong sedang.
\end{abstract}

Katakunci: indeks pembangunan berwawasan kependudukan (IPBK), Indeks pembangunan manusia (IPM)

\section{A. PENDAHULUAN}

\section{Latar Belakang}

Jumlah penduduk dunia mengalami peningkatan pesat sejak tahun 1650 ketika revolusi industri terjadi (Mantra, 2000). Adanya revolusi industri ini berdampak ke banyak aspek kehidupan manusia seperti pertanian, pangan, dan energi. Fasilitas kesehatan yang semakin membaik berdampak mengurangi kematian bayi dan meningkatkan harapan hidup manusia. Hasil pertanian yang meningkat menjadikan persediaan pangan untuk manusia tinggi. Hal tersebut menjadi faktor dibalik terus meningkatnya jumlah penduduk dunia hingga mencapai hampir 8 miliar pada tahun 2016. 
Jumlah penduduk yang semakin meningkat menjadikan kekuatiran beberapa ahli. Thomas Malthus menyatakan bahwa pertumbuhan penduduk yang semakin meningkat suatu saat akan mencapai titik kritis dimana suplai makanan tidak mampu lagi mencukupi kebutuhan manusia (Mantra, 2000). Keadaan ini akan menyebabakan kelaparan di seluruh dunia yang dapat memicu peperangan dan kematian massal.

Sementara itu, pertumbuhan penduduk yang semakin meningkat juga menimbulkan dampak negatif terhadap lingkungan. Kebutuhan manusia yang tinggi menjadikan pembangunan tidak memperhatikan kelestarian lingkungan. Perubahan iklim menyebabkan naiknya muka air laut dan degradasi lingkungan pesisir. Selain itu, penggundulan hutan oleh alih fungsi lahan juga menyebabkan bencana yang dipicu aktivitas mulai banyak terjadi.

Pandangan pesimis terhadap sumberdaya manusia diatas menimbulkan perlunya suatu konsep untuk menaggulangi dampak yang terjadi. Penilaian terhadap sumberdaya manusia merupakan salah satu konsep yang mulai dilakukan oleh para ahli dunia. Penilaian ini bertujuan untuk melakukan evaluasi terhadap kondisi sumberdaya manusia yang ada untuk kemudian dapat dilakukan analisis terhadapnya. Indeks Pembangunan Berwawasan Kependudukan (IPBK) salah satu metode yang dapat digunakan untuk mengukur SDM. SDM yang bernilai baik tentunya akan menjadikan kehidupan bumi menjadi lebih baik.

\section{Tujuan}

1. Menganalisis IPBK Provinsi Bengkulu pada tahun 2014.

2. Menganalisis hubungan IPBK dan IPM Provinsi Bengkulu pada tahun 2014.

\section{B. METODE PENELITIAN}

\section{IPM}

Human development atau pembangunan manusia merupakan suatu proses untuk memperbesar pilihan-pilihan bagi manusia (UNDP, 1990). Teori ini dicetuskan oleh UNDP untuk memperbaiki konsep analisis sumber daya 
manusia sebelumnya yang berlandaskan produk domestik bruto atau rata-rata pendapatan perkapita. Menurut UNDP (1990), pendapatan rata-rata tidak secara detil menggambarkan kondisi sumberdaya manusia di suatu wilayah. Hal ini karena kesenjangan antara penduduk kaya dan miskin cenderung tinggi, sehingga penduduk yang pada dasarnya miskin akan terdata memiliki kesejahteraan lebih tinggi. Sementara itu, pembangunan manusia dalam mencapai tujuan akhirnya memperhatikan empat hal utama, yaitu:

1. Produktifitas: Produktifitas penduduk berkaitan dengan human capital yang dimiliki dan investasi manusia dilakukan untuk meningkatnya.

2. Pemerataan: Penduduk memiliki kesempatan yang sama untuk mendapatkan akses terhadap sumber daya ekonomi dan sosial. Semua hambatan yang memperkecil kesempatan untuk memperoleh akses tersebut harus dihapus.

3. Kesinambungan: Pembangunan yang dilakukan tidak hanya untuk mencukupi kebutuhan saat ini tapi juga masa depan.

4. Pemberdayaan: Penduduk harus berpartisipasi penuh dalam keputusan dan proses yang akan menentukan kehidupan mereka.

Pengukuran terhadap pembangunan manusia menggunakan konsep yang disebut dengan Human Developmen Index (HDI) (UNDP, 1990). Komponen pengukuran dalam HDI terdiri dari tiga, yaitu:

1. Indeks Harapan hidup

Indeks Harapan Hidup menunjukkan jumlah tahun hidup yang diharapkan dapat dinikmati penduduk suatu wilayah. Dengan memasukkan informasi mengenai angka kelahiran dan kematian per tahun, variabel tersebut diharapkan akan mencerminkan rata-rata lama hidup sekaligus hidup sehat masyarakat.

2. Indeks Hidup Layak

Standar hidup layak diukur menggunakan PDRB per kapita yang dianggap menggambarkan kesejahteraan ekonomi masyarakat.

3. Indeks Pendidikan 
Penghitungan Indeks Pendidikan (IP) mencakup dua indikator yaitu angka melek huruf dan rata-rata lama sekolah. Populasi yang digunakan adalah penduduk berumur 15 tahun ke atas karena pada kenyataannya penduduk usia tersebut sudah ada yang berhenti sekolah. Kedua indikator pendidikan ini dimunculkan dengan harapan dapat mencerminkan tingkat pengetahuan.

\section{IPBK}

People centered development atau pembagunan berwawasan kependudukan merupakan suatu konsep yang dicetuskan dalam International Conference on Population and Development (ICPD). Konferensi ini digagas oleh United Nations Population Fund (UNFPA) di Kairo , Mesir pada 5-13 September 1994. Dokomen ICPD sendiri terdiri dari 15 pasal yang selanjutnya dijabarkan menjadi 16 POA (Plane of Actions) yang dirincikan dalam 44 dimensi. Dokumen tersebut dilakukan evaluasi setiap 10 tahun sekali yaitu pada 2004 dan 2014. Evaluasi tersebut dilakukan karena keadaan dunia selalu berubah. Oleh karena itu isi dari dokumen ICPD perlu menyesuaikan.

Pembangunan berwawasan kependudukan adalah konsep dimana penduduk diletakkan sebagai sentral pembangunan, yaitu sebagai subyek dan obyek. Sebagai subjek pembangunan maka penduduk harus dibina dan dikembangkan agar mampu menjadi penggerak pembangunan. Sebagai objek, penduduk juga harus dapat menikmati pembangunan yang bersangkutan (Tjiptoherijanto, 2010).

Konsep kebijakan pembangunan ini terdiri dari population-responsive policy (kebijakan pembangunan yang senantiasa mengacu atau merujuk kepada dinamika dan tren perkembangan kependudukan), dan population influencing policy (kebijakan pembangunan yang diarahkan untuk membentuk dinamika dan struktur penduduk seperti yang diinginkan). Contoh konsep population-responsive policy adalah:

1. Adanya junlah penduduk usia kerja yang besar, maka pemrintah harus menyediakan lapangan kerja. 
2. Jumlah populasi remaja yang besar harus direspon oleh pemerintah dengan program pendidikan dan kesehatan reproduksi remaja.

3. Penduduk lansia besar direspon dengan peningkatan kesehatan dan kesejahteraan.

Sementara itu, contoh konsep population- influencing policy adalah jumlah penduduk yang tinggi, kualitas penduduk yang rendah, dan persebaran penduduk tidak merata direspon pemerintah dengan membangun suatau grand desaign pembangunan kependudukan dengan tujaan pengendalian kuantitas, peningkatan kualitas, dan pengarahan mobilitas (Jalal, 2014).

Pembangunan berwasasn kependudukan terdiri dari empat konsep pembanguan yang saling terkait, yaitu: Pembangunan berkelanjutan (Sustainable Development), Pembangunan Sumberdaya manusia (PSDM), Pembangunan Manusia (Human Development), Pembangunan berwawasan kependudukan (People Centered Development). Hubungan antar konsep tersebut dapat dilihat di.

Pengukuran pembagunan berwawasan kependudukan menggunakan IPBK (Indeks Pembagunan Berwawasan Kependudukan). Indeks tersebut mengggunakan lima dimensi dalam pengukurannya, yaitu: partisipasi masyarakat, keberlanjutan, integrasi, pemihakan terhadap rakyat miskin, dan kesetaraan (Jalal, 2014).

\section{HASIL DAN PEMBAHASAN}

IPBK Provinsi Bengkulu tahun 2014 memiliki nilai 0.411 (Tabel 1). Nilai tersebut tergolong kelas sedang apabila dibandingkan secara nasional maupun diklasifikasikan menggunakan metode equal ranges (Tabel 2). Nilai IPBK provinsi tersebut berasal dari rata-rata nilai dimensi dari setiap kabupaten/kota yang ada.

Tabel 1: IPBK dan IPM Tahun 2014

\begin{tabular}{|c|c|c|c|c|c|c|c|c|c|}
\hline Prov & Kab & IPBK & $\begin{array}{c}\text { Kelas } \\
\text { IPBK } \\
\text { (nasional) }\end{array}$ & $\begin{array}{c}\text { IPBK } \\
\text { Prov }\end{array}$ & $\begin{array}{c}\text { Kelas } \\
\text { Nasional }\end{array}$ & IPM & $\begin{array}{c}\text { Kelas IPM } \\
\text { (nasional) }\end{array}$ & $\begin{array}{c}\text { IPM } \\
\text { Prov }\end{array}$ & $\begin{array}{c}\text { Kelas } \\
\text { Nasional }\end{array}$ \\
\hline Bengkulu & $\begin{array}{c}\text { BENGKULU } \\
\text { SELATAN }\end{array}$ & 0.473 & $\begin{array}{c}\text { Sangat } \\
\text { Tinggi }\end{array}$ & 0.411 & Sedang & 68.28 & Tinggi & 66.38 & Sedang \\
\hline
\end{tabular}




\begin{tabular}{|c|c|c|c|c|c|c|c|c|c|}
\hline Prov & Kab & IPBK & $\begin{array}{c}\text { Kelas } \\
\text { IPBK } \\
\text { (nasional) }\end{array}$ & $\begin{array}{l}\text { IPBK } \\
\text { Prov }\end{array}$ & $\begin{array}{c}\text { Kelas } \\
\text { Nasional }\end{array}$ & IPM & $\begin{array}{l}\text { Kelas IPM } \\
\text { (nasional) }\end{array}$ & $\begin{array}{l}\text { IPM } \\
\text { Prov }\end{array}$ & $\begin{array}{c}\text { Kelas } \\
\text { Nasional }\end{array}$ \\
\hline & REJANG LEBONG & 0.391 & Tinggi & & & 66.55 & Tinggi & & \\
\hline & BENGKULU UTARA & 0.428 & Tinggi & & & 67.27 & Tinggi & & \\
\hline & KAUR & 0.428 & Tinggi & & & 63.75 & Tinggi & & \\
\hline & SELUMA & 0.375 & Sedang & & & 62.94 & Tinggi & & \\
\hline & MUKOMUKO & 0.453 & Tinggi & & & 65.31 & Tinggi & & \\
\hline & LEBONG & 0.354 & Sedang & & & 63.90 & Tinggi & & \\
\hline & KEPAHIANG & 0.403 & Tinggi & & & 65.22 & Tinggi & & \\
\hline & BENGKULU TENGAH & 0.387 & Sedang & & & 64.10 & Tinggi & & \\
\hline & BENGKULU & 0.417 & Tinggi & & & 76.49 & $\begin{array}{c}\text { Sangat } \\
\text { Tinggi }\end{array}$ & & \\
\hline
\end{tabular}

Sumber: Analisis, 2016

Tabel 2: Klasifikasi IPBK Metode Equal Ranges

\begin{tabular}{|c|c|c|}
\hline \multirow{2}{*}{ Kelas } & \multicolumn{2}{|c|}{ Range } \\
\cline { 2 - 3 } & Min & Max \\
\hline sangat rendah & 0 & 0.2 \\
\hline rendah & 0.21 & 0.4 \\
\hline sedang & 0.41 & 0.6 \\
\hline tinggi & 0.61 & 0.8 \\
\hline sangat tinggi & 0.81 & 1 \\
\hline
\end{tabular}

Sumber: Analisis, 2016

IPBK Provinsi Bengkulu diukur menggunakan 5 dimensi, yaitu partisipasi (Tabel 3), keberlangsungan (Tabel 4), Keberpihakan (Tabel 5), Integrasi (Tabel 6), dan Kesetaraan (Tabel 7). Setiap dimensi tersebut terdiri dari parameterparameter pengukuran. Indeks dari setiap parameter inilah yang menjadi indeks dari dimensi. IPBK didapatkan dari rata-rata indeks dimensi.

Tabel 3: Indeks Dimensi Partisipasi

\begin{tabular}{|c|c|c|c|c|c|c|c|c|c|c|c|}
\hline \multirow[b]{2}{*}{ Prov } & \multirow[b]{2}{*}{ Kab } & \multicolumn{10}{|c|}{ Partisipasi } \\
\hline & & 103 & 104 & 105.1 & 105.2 & 105.3 & 106 & 111 & 113 & Indeks & $\begin{array}{l}\text { Index } \\
\text { Provinsi }\end{array}$ \\
\hline \multirow{5}{*}{ Bengkulu } & $\begin{array}{c}\text { BENGKULU } \\
\text { SELATAN }\end{array}$ & 0.81 & 0.93 & 0.98 & 0.81 & 0.89 & 0.41 & 0.94 & 0.38 & 0.77 & \multirow{5}{*}{0.74} \\
\hline & $\begin{array}{l}\text { REJANG } \\
\text { LEBONG }\end{array}$ & 0.93 & 0.98 & 0.98 & 0.73 & 0.69 & 0.47 & 0.95 & 0.43 & 0.77 & \\
\hline & $\begin{array}{l}\text { BENGKULU } \\
\text { UTARA }\end{array}$ & 0.88 & 0.90 & 0.99 & 0.69 & 0.74 & 0.44 & 0.85 & 0.42 & 0.74 & \\
\hline & KAUR & 0.83 & 0.92 & 0.98 & 0.86 & 0.72 & 0.38 & 0.85 & 0.36 & 0.74 & \\
\hline & SELUMA & 0.92 & 0.96 & 0.99 & 0.80 & 0.68 & 0.43 & 0.78 & 0.41 & 0.75 & \\
\hline
\end{tabular}




\begin{tabular}{|c|c|c|c|c|c|c|c|c|c|c|c|}
\hline \multirow[b]{2}{*}{ Prov } & \multirow[b]{2}{*}{ Kab } & \multicolumn{10}{|c|}{ Partisipasi } \\
\hline & & 103 & 104 & 105.1 & 105.2 & 105.3 & 106 & 111 & 113 & Indeks & $\begin{array}{l}\text { Index } \\
\text { Provinsi }\end{array}$ \\
\hline & MUKOMUKO & 0.78 & 0.83 & 0.97 & 0.85 & 0.72 & 0.32 & 0.93 & 0.28 & 0.71 & \\
\hline & LEBONG & 1.00 & 0.73 & 0.92 & 0.75 & 0.72 & 0.43 & 0.82 & 0.41 & 0.72 & \\
\hline & KEPAHIANG & 0.98 & 0.86 & 0.94 & 0.70 & 0.80 & 0.44 & 0.96 & 0.40 & 0.76 & \\
\hline & $\begin{array}{l}\text { BENGKULU } \\
\text { TENGAH }\end{array}$ & 0.93 & 1.00 & 0.98 & 0.71 & 0.59 & 0.34 & 0.81 & 0.32 & 0.71 & \\
\hline & BENGKULU & 0.78 & 0.98 & 0.97 & 0.79 & 0.74 & 0.28 & 0.99 & 0.27 & 0.72 & \\
\hline
\end{tabular}

Sumber: Analisis, 2016

Tingkat partisipasi masyarakat Bengkulu dapat dilihat pada Tabel 3. Indeks partisipasi secara keseuruhan bernilai 0.74 (tinggi menurut equal ranges). Tingginya indeks ini tidak terlepas dari nilai parameter-parameter disetiap kabupaten yang relative tinggi. Parameter yang memiliki nilai rendah hingga sedang adalah 106 (persentase penduduk yang bekerja per penduduk usia kerja) dan 113 (TPAK). Kota Bengkulu memiliki kedua indeks paling rendah yaitu 0,28 dan 0,27. Rendahnya TPAK ini diakibatkan banyaknya penduduk yang tergolong bukan angkatan kerja yang terutama diakibatkan oleh penduduk yang bersekolah.

Tabel 4: Indeks Dimensi Keberlangsungan

\begin{tabular}{|c|c|c|c|c|c|c|c|c|c|}
\hline \multirow[b]{2}{*}{ Prov } & \multirow[b]{2}{*}{ Kab } & \multicolumn{8}{|c|}{ Keberlansungan } \\
\hline & & 202 & 203 & $\left.204^{*}\right)$ & $\left.205^{\star}\right)$ & 207 & 209 & Indeks & $\begin{array}{l}\text { Index } \\
\text { Provinsi }\end{array}$ \\
\hline \multirow{10}{*}{ Bengkulu } & $\begin{array}{l}\text { BENGKULU } \\
\text { SELATAN }\end{array}$ & 0.16 & 0.20 & 0.01 & 0.14 & 0.34 & 0.45 & 0.22 & \multirow{10}{*}{0.18} \\
\hline & $\begin{array}{l}\text { REJANG } \\
\text { LEBONG }\end{array}$ & 0.15 & 0.10 & 0.01 & 0.25 & 0.31 & 0.13 & 0.16 & \\
\hline & $\begin{array}{l}\text { BENGKULU } \\
\text { UTARA }\end{array}$ & 0.09 & 0.18 & 0.00 & 0.14 & 0.31 & 0.27 & 0.17 & \\
\hline & KAUR & 0.13 & 0.11 & 0.00 & 0.11 & 0.21 & 0.26 & 0.14 & \\
\hline & SELUMA & 0.08 & 0.13 & 0.01 & 0.15 & 0.24 & 0.28 & 0.15 & \\
\hline & MUKOMUKO & 0.06 & 0.16 & 0.00 & 0.08 & 0.45 & 0.29 & 0.17 & \\
\hline & LEBONG & 0.13 & 0.18 & 0.00 & 0.13 & 0.35 & 0.21 & 0.17 & \\
\hline & KEPAHIANG & 0.17 & 0.16 & 0.01 & 0.12 & 0.27 & 0.12 & 0.14 & \\
\hline & $\begin{array}{l}\text { BENGKULU } \\
\text { TENGAH }\end{array}$ & 0.09 & 0.36 & 0.00 & 0.18 & 0.21 & 0.24 & 0.18 & \\
\hline & BENGKULU & 0.28 & 0.15 & 0.01 & 0.19 & 0.68 & 0.75 & 0.34 & \\
\hline
\end{tabular}

Sumber: Analisis, 2016

Indeks dimensi keberlangsungan (Tabel 4) tergolong sangat rendah berdasarkan klasifikasi equal ranges. Hal ini diakibatkan hanya 2 dari 6 parameter 
yang rata-rata memiliki indeks sedang, sementara yang lain rendah hingga sangat rendah. Parameter yang rerata tergolong sedang adalah 207 (air minum layak) dan 209 (sanitasi). Kota Bengkulu memiliki indeks tinggi pada kedua parameter ini karena daerah ini merupakan perkotaan yang telah lebih maju dibandingkan kabupaten/kota lain. Sementara itu, paramerer yang buruk di semua kabupaten/kota adalah anggaran untuk konservasi (203), desa dengan pencemaran (204), kepadatan penduduk sektor pertanian (204), dan persentase luas lahan pertanian(205).

Indeks dimensi keberpihakan menunjukkan nilai 0,47 yang tergolong sedang (Tabel 5). Parameter 302 (Persentase APBD untuk kesehatan) yang tergolong rendah hingga sangat rendah merupakan penyebab indeks dimensi keberpihakan sedang. Kabupaten Muko-Muko memilki pengecualian karena memiliki indeks 302 yang tinggi. Indeks 301 (Persentase APBD untuk pendidikan) tergolong rerata sedang dan parameter 303 (APBD) untuk penanggulangan kemiskinan rerata sedang hingga tinggi.

Tabel 5: Indeks Dimensi Keberpihakan

\begin{tabular}{|c|c|c|c|c|c|c|}
\hline \multirow[b]{2}{*}{ Prov } & \multirow[b]{2}{*}{ Kab } & \multicolumn{5}{|c|}{ Keberpihakan } \\
\hline & & 301 & 302 & 303 & Indeks & $\begin{array}{l}\text { Index } \\
\text { Provinsi }\end{array}$ \\
\hline \multirow{10}{*}{ Bengkulu } & $\begin{array}{l}\text { BENGKULU } \\
\text { SELATAN }\end{array}$ & 0.63 & 0.36 & 0.72 & 0.57 & \multirow{10}{*}{0.47} \\
\hline & $\begin{array}{l}\text { REJANG } \\
\text { LEBONG }\end{array}$ & 0.61 & 0.34 & 0.69 & 0.55 & \\
\hline & $\begin{array}{l}\text { BENGKULU } \\
\text { UTARA }\end{array}$ & 0.60 & 0.32 & 0.68 & 0.54 & \\
\hline & KAUR & 0.26 & 0.28 & 0.35 & 0.29 & \\
\hline & SELUMA & 0.54 & 0.33 & 0.64 & 0.50 & \\
\hline & MUKOMUKO & 0.42 & 0.64 & 0.69 & 0.59 & \\
\hline & LEBONG & 0.39 & 0.19 & 0.41 & 0.33 & \\
\hline & KEPAHIANG & 0.54 & 0.28 & 0.59 & 0.47 & \\
\hline & $\begin{array}{l}\text { BENGKULU } \\
\text { TENGAH }\end{array}$ & 0.46 & 0.19 & 0.50 & 0.38 & \\
\hline & BENGKULU & 0.68 & 0.19 & 0.68 & 0.51 & \\
\hline
\end{tabular}

Sumber: Analisis, 2016

Indeks dimensi integrasi (Tabel 6) menunjukkan kelas yang sangat rendah $(0,17)$. Parameter yang diukur di dimensi ini hanya satu yaitu 403 (Persentase 
APBD untuk program kependudukan dan KB). Hasil analisis menunjukkan bahwa nilai disetiap kabupaten tergolong rendah hingga sangat rendah kecuali pada Bengkulu Selatan yang sangat tinggi. Hal ini menunjukkan bahwa komitmen pemerintah terhadap masalah kependudukan dan KB masih sangat rendah.

Tabel 6: Indeks Dimensi Integrasi

\begin{tabular}{|c|c|c|c|c|}
\hline \multirow[b]{2}{*}{ Prov } & \multirow[b]{2}{*}{ Kab } & \multicolumn{3}{|c|}{ Integrasi } \\
\hline & & 403 & Indeks & $\begin{array}{l}\text { Index } \\
\text { Provinsi }\end{array}$ \\
\hline \multirow{10}{*}{ Bengkulu } & $\begin{array}{l}\text { BENGKULU } \\
\text { SELATAN }\end{array}$ & 0.87 & 0.34 & \multirow{10}{*}{0.17} \\
\hline & REJANG LEBONG & 0.00 & 0.00 & \\
\hline & $\begin{array}{c}\text { BENGKULU } \\
\text { UTARA }\end{array}$ & 0.23 & 0.09 & \\
\hline & KAUR & 1.11 & 0.43 & \\
\hline & SELUMA & 0.16 & 0.06 & \\
\hline & MUKOMUKO & 1.01 & 0.39 & \\
\hline & LEBONG & 0.24 & 0.09 & \\
\hline & KEPAHIANG & 0.36 & 0.14 & \\
\hline & $\begin{array}{c}\text { BENGKULU } \\
\text { TENGAH }\end{array}$ & 0.23 & 0.09 & \\
\hline & BENGKULU & 0.14 & 0.05 & \\
\hline
\end{tabular}

Sumber: Analisis, 2016

Indeks dimensi kesetaraan (Tabel 7) menunjukkan kelas sedang $(0,49)$. Paraeter 501 (Angka Partisipasi Sekolah Perempuan) tergolong tinggi hingga sangat tinggi diseluruh kabupaten/kota. Parameter 502 (alokasi APBD untuk pemberdayaan perempuan) tergolong rendah hingga sangat rendah kecuali untuk kabupaten Bengkulu Tengah dan Bengkulu Utara yang tergolong tinggi. Sementara itu, TPAK perempuan menunjukkan kelas sedang. Parameter APBD untuk perempuan merupakan faktor penghambat pada dimensi ini.

IPBK Provinsi Bengkulu apabila dibandingkan dengan provinsi seluruh Indonesia tergolong kelas sedang (Tabel 1). Persebaran IPBK seluruh Indonesia dapat dilihat pada lampiran peta. Dimensi yang masih dapat ditingkatkan indeksnya adalah keberlangsungan dan integrasi. Provinsi Bengkulu terlihat belum konsen terhadap konsep keberlanjutan, Hal ini terlihat dari anggaran pemerintah 
maupun program yang dicanangkan masih rendah terhadap lingkungan yang berdampak pada pencemaran dan pemanfaatan pertanian rendah.

Tabel 7: Indeks Dimensi Kesetaraan

\begin{tabular}{|c|c|c|c|c|c|c|}
\hline \multirow[b]{2}{*}{ Prov } & \multirow[b]{2}{*}{ Kab } & \multicolumn{5}{|c|}{ Kesetaraan } \\
\hline & & 501 & 502 & 503 & Indeks & $\begin{array}{l}\text { Index } \\
\text { Provinsi }\end{array}$ \\
\hline \multirow{10}{*}{ Bengkulu } & $\begin{array}{c}\text { BENGKULU } \\
\text { SELATAN }\end{array}$ & 0.82 & 0.14 & 0.46 & 0.47 & \multirow{10}{*}{0.49} \\
\hline & $\begin{array}{l}\text { REJANG } \\
\text { LEBONG }\end{array}$ & 0.74 & 0.22 & 0.49 & 0.48 & \\
\hline & $\begin{array}{c}\text { BENGKULU } \\
\text { UTARA }\end{array}$ & 0.72 & 0.65 & 0.46 & 0.61 & \\
\hline & KAUR & 0.80 & 0.38 & 0.44 & 0.54 & \\
\hline & SELUMA & 0.81 & 0.01 & 0.42 & 0.41 & \\
\hline & MUKOMUKO & 0.73 & 0.21 & 0.28 & 0.41 & \\
\hline & LEBONG & 0.74 & 0.22 & 0.43 & 0.46 & \\
\hline & KEPAHIANG & 0.71 & 0.36 & 0.43 & 0.50 & \\
\hline & $\begin{array}{c}\text { BENGKULU } \\
\text { TENGAH }\end{array}$ & 0.71 & 0.68 & 0.33 & 0.57 & \\
\hline & BENGKULU & 0.86 & 0.11 & 0.37 & 0.45 & \\
\hline
\end{tabular}

Sumber: Analisis, 2016

IPBK tingkat kabupaten/kota tergolong tinggi hingga sangat tinggi kecuali pada Kabupaten Seluma, Lebong, dan Bengkulu Tengah. Ketiga kabupaten ini tertinggal dari kebupaten yang lain dalam hal keberlangsungan, integrasi, dan keberpihakan. Pemerintah daerah harus lebih konsen terhdap ketiga dimensi tersebut karena dalam Provinsi Bengkulu ketiga provinsi ini memiliki nilai yang selalu rendah.

Perbandingan antara IPBK dan IPM dapat dilihat pada Tabel 1. Nilai IPM di seluruh kabupaten tergolong tinggi, sedangkan di Kota Bengkulu tergolong sangat tinggi. Nilai IPM dapat dikatakan berbanding lurus dengan IPBK Provinsi Bengkulu. Hal ini dikarenakan parameter pengukuran evaluasi dari kedua metode saling berkolerasi. IPM menggunakan tiga dimensi, yaitu kesehatan, pendidikan, dan produktifitas, sedangkan IPBK menggunakan lima dimensi yang telah sijelaskan diatas. 


\section{KESIMPULAN}

1. IPBK Provinsi Bengkulu di tahun 2014 tergolong kelas sedang di tingkat Indonesia, sedangkan kabupaten/kota tergolong tinggi higga sangat tinggi kecuali Kabupaten Seluma, Lebong, dan Bengkulu Tengah yang tergolong sedang.

2. IPBK dan IPM Provinsi Bengkulu menunjukkan korelasi yang positif . Hal ini dikarenakan dimensi pengukuran kedua metode saling berkorelasi. IPBK dan IPM Provinsi Bengkulu tergolong sedang.

\section{DAFTAR PUSTAKA}

Hanapiah, Ali. 2011. Analisis Investasi Modal Manusia Dalam Perspektif Pendidikan Dan Pelatihan. Jatinagor: IPDN.

Jalal, Fasli. 2014. Pembangunan Berwawasan Kependudukan. Seminar Nasional Kependudukan. Bandung: BKKBN.

Mantra, Ida Bagoes. 2000. Demografi Umum. Yogyakarta: Pustaka Pelajar

Schultz, T. W. 1961. Investment in Human Capital. American Economic Review, 51, $1-17$.

UNDP. 1990. Human Development Report 1990. New York: Oxford University Press.

Tjiptoherijanto, Prijanto. 2010. Menuju Pembangunan Berwawasan Kependudukan. Jurnal Populasi. Yogyakarta: UGM. 